\title{
Energy metabolism in the digestive tract and liver of cattle: influence of physiological state and nutrition *
}

\author{
GB Huntington \\ US Department of Agriculture, Agricultural Research Service, Beltsville, MD 20705, USA
}

(Received 10 June 1989; accepted 17 October 1989)

\begin{abstract}
Summary - Major functions of portal-drained viscera (PDV) and liver of cattle include absorption of digestion products and modification of the body's supply of intermediary metabolites. The disproportionately high metabolic rate of PDV and liver (7-13\% of body tissues) is exemplified by their oxygen uptake (40-50\% of whole body). Extensive metabolism of glucose, volatile fatty acids and amino acids by PDV modulates nutrient supply from the diet such that most responses to diet or physiological state are a function of level of diet intake. Similarly, blood flow through PDV is highly correlated with energy intake across a range of body weight, physiological state or diet composition. Most common dietary responses in metabolite uptake by PDV are changes in uptake of ammonia and volatile fatty acids, which emphasize the strong energy: nitrogen interrelationship in the rumen and subsequently the rest of the body. The liver (tissue in series with PDV) removes glucose precursors and ammonia from its blood supply as part of its functions in gluconeogenesis, ammonia detoxification and urea synthesis. The liver also alters amounts and proportions of amino acids supplied by PDV. Accountable percentages of metabolizable energy from net PDV supply include: organic acids, 41-59\%; amino acids, 5-13\%; and heat energy (from oxygen uptake), 11-22\%.
\end{abstract}

\section{cattle / gastrointestinal tract / liver / absorption / metabolism}

Résumé - Métabolisme énergétique au niveau du tractus digestif et du fole chez les bovins : influence du stade physiologique et de l'état nutritionnel. La digestion et le métabolisme des nutriments fournis à l'organisme comptent parmi les principales fonctions du tractus digestif (plus le pancréas, la rate et tissu adipeux mésentérique) et du foie. L'activité métabolique intense du tractus digestif et du foie (qui ne représentent que 7 a $13 \%$ du poids corporel) se traduit par leur consommation élevée d'oxygène (40 à $50 \%$ de celle de l'organisme entier). Le métabolisme intense du glucose, des acides gras volatils et des acides aminés dans le tractus digestif et le foie module l'apport de nutriments à tel point que la plupart des réponses aux modifications de la composition du régime et du stade physiologique de l'animal dépendent essentiellement du niveau d'alimentation. Le flux sanguin à travers le tractus digestif est également étroitement corrélé avec la consommation d'énergie pour une grande gamme de poids vifs, d'états physiologiques et de compositions des régimes. Les variations d'origine alimentaire des prélèvements de nutriments par le tractus digestif concernent généralement l'ammoniaque et les acides gras volatils, ce qui souligne les relations étroites azote-énergie dans le rumen et, par suite, dans l'ensemble de l'organisme. Le foie lorgane placé en série après le tractus digestif) prélève les précurseurs du glucose et l'ammoniaque du sang porte pour la néoglucogenèse, la détoxication de l'ammoniaque et la synthèse d'urée. Le foie modifie également les quantités et les proportions d'acides aminés absorbés. L'ensemble des acides organiques absorbés représente de 41 à $59 \%$ de l'énergie métabolisable, les acides aminés de 5 à $13 \%$ et l'énergie dissipée sous forme de chaleur (déterminée à partir de la consommation d'oxygène du tractus digestif) de 11 à $22 \%$.

\section{bovin / tractus digestif / foie / absorption / métabolisme}

\footnotetext{
* Presented at the 5th Conference on Nutrition and Feeding of Herbivores, INRA, Paris, 16-17 March, 1989
} 


\section{INTRODUCTION}

Domesticated ruminants are perhaps the most versatile omnivores in the world, obtaining nutrition from forages, non-protein nitrogen $(\mathrm{N})$ sources, cereal grains, legumes and feedstuffs of animal origin. Concomitantly, domesticated ruminants use their diets with a wide range of partial efficiencies. For example, use of metabolizable energy (ME) for growth can be as low as 0.21 for forages and as high as 0.65 for energetically dense diets [ARC (Agricultural Research Council, 1980)]. The ME not retained as tissue or released as milk is lost as heat energy (HE).

In most animals, including domesticated ruminants, the portal-drained viscera (PDV) is the interface between the diet and the organism. The liver, tissue in series with the PDV, is the central metabolic intersection between PDV and the rest of the body. Major functions of the splanchnic tissues (PDV and liver) are digestion and absorption of dietary nutrients, supply of a plethora of hormones and immune response. This review will focus on digestive and absorptive functions of cattle. The terms "gut" and "PDV" will be used synonymously, although PDV includes the pancreas, spleen and fat associated with the gut.

Metabolic function and therefore energy metabolism of splanchnic tissues responds to a variety of environmental stimuli, including heat (McGuire et al, 1989), cold (Sasaki and Weekes, 1986), fasting or level of feed intake (Lomax and Baird, 1983; Ferrell, 1988), diet composition and productive (physiological) state. The objective of this review is to describe effects of the latter two stimuli on function and energy metabolism of PDV and liver of beef and dairy cattle. Data used were derived mainly from use of one approach, in vivo fluxes across PDV and liver of multi- catheterized cattle (Huntington et al, 1989). Discussion of physiological state will center on growth or lactation.

\section{PORTAL BLOOD FLOW AND ME IN- TAKE}

There is a positive direct relationship between blood flow through PDV and ME intake in cattle and sheep. Linear (Huntington, 1984a; Weighart et al, 1986) or curvilinear (Webster et al, 1975; Lomax and Baird, 1983) regressions of portal blood flow on energy intake likely apply to liver blood flow as well, because liver blood flow derives predominantly from PDV. Figure 1 is a summary of 16 treatment means from studies with cattle from which estimates of average hourly portal blood flow are available, and treatments were intakes within diets. The characteristics of the cattle ranged from fasted beef steers $(200 \mathrm{~kg})$ to lactating dairy cows $(650$ $\mathrm{kg}$ ) eating ME equal to 3 times their maintenance requirement. Diets ranged from forage to high concentrate diets. One can regress with high $\mathrm{r}^{2}$ linear or curvilinear relationships among the data points (fig 1), with the bulk of the data between 40-100 $\mathrm{MJ} / \mathrm{d}$ ME intake. Comparison of 11 portal blood flows from studies not used to generate these regressions (Huntington et al, 1981; Eisemann and Huntington, 1987; Harmon and Avery, 1987; Gross et al, 1988; Harmon et al, 1988; Huntington, 1989) showed good predictability. Mean \pm SE of predicted divided by observed portal blood flow was $1.00 \pm 0.04$ for the exponential fit and $1.07 \pm 0.04$ for the linear fit (fig 1). The ME intakes in the studies used in the comparison ranged from 40-81 $\mathrm{MJ} /$ d.

Daily ME intake is highly correlated with other factors that may influence portal (or hepatic) blood flow, including breed, live 


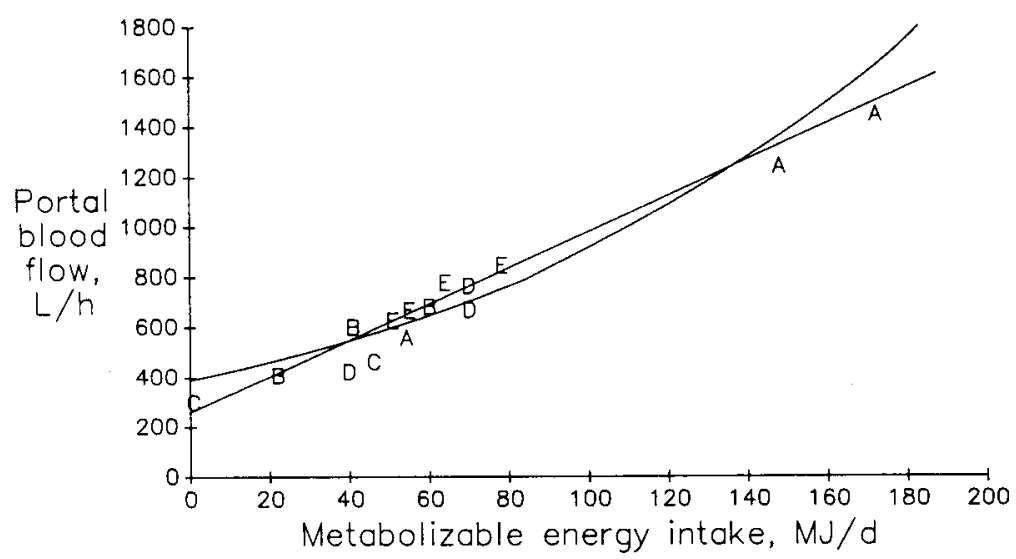

Fig 1. Linear and exponential relationships between metabolizable energy intake $(x)$ and portal blood flow $(y)$. The linear equation is $y=259+7.24 x ; r=0.98$. The exponential equation is $y=391 e^{0.0084 x}$, $r=0.94$. Observations (16) are treatment means from the following sources : A, Holstein cows (Huntington et al, 1983; Huntington, 1984b; Reynolds et al, 1988); B, Beef heifers (Huntington and Prior, 1983); C, Beef steers (Huntington et al, 1988); D, Beef heifers (Reynolds and Tyrrell, 1989). One value is hidden in the figure; $\mathrm{E}$, Holstein steers (Huntington et al, 1988).

weight (or some exponent thereof) and energy density of the diet. However, direct (Huntington, 1984a) or implied (Weighart et al, 1986) evalution of these factors did not improve $r^{2}$. From a more physiological perspective, portal blood flow ranges from 25-52 $\mathrm{ml} \cdot \mathrm{min}^{-1} \cdot \mathrm{kg}^{-1}$ body weight with a median value of $\approx 40$ in cattle (Carr and Jacobson, 1968; Wangness and McGilliard, 1972; Harmon and Avery, 1987; Durand et al, 1988; Reynolds et al, 1988).

Teleologically, portal and hepatic blood flow increase in response to increased $M E$ intake to transport digested nutrients from the gut, through the liver, and on to the rest of the body. Heart rate and thereby cardiac output likewise increase with increased intake (Rumsey et al, 1980). Whether or not productive state or dietary composition directly alter the proportion of cardiac output flowing through splanchnic tissues remains to be determined. A pre- liminary report with beef steers (Huntington et al, 1988) indicates that these proportions are similar in fed and fasted steers, but change in acute response to a $\beta$ adrenergic agonist.

\section{OXYGEN UPTAKE BY SPLANCHNIC TISSUES}

In vivo measurements of oxygen uptake by PDV and liver of cattle provide estimates of $\mathrm{HE}$ attributable to those tissues (table 1). Over a wide range of body weights and productive states the PDV accounts for $18-25 \%$ and the liver $17-25 \%$ of whole body oxygen uptake, or energy lost as HE. Similar or appreciably higher proportions of whole body oxygen uptake by splanchnic tissues have been reported for sheep (Thompson et al, 1978; Burrin et al, 1989). The PDV are $6.4-10 \%$ of body tissues, 
Table I. Portions of whole body oxygen uptake attributable to portal-drained viscera (PDV), liver and total splanchnic (TS) tissues of cattle. a Huntington et al (1988); b Huntington and Tyrrell (1985); c Reynolds et al (1986); d Huntington and Eisemann (unpublished); $\theta$ Huntington et al (1989); ' Reynolds and Tyrrell (1989).

\begin{tabular}{lrrrrrr}
\hline & $\begin{array}{l}\text { Dairy } \\
\text { steers a }\end{array}$ & $\begin{array}{l}\text { Lactating } \\
\text { cows b }\end{array}$ & $\begin{array}{l}\text { Lactating } \\
\text { cows c }\end{array}$ & $\begin{array}{l}\text { Beef } \\
\text { steers d }\end{array}$ & $\begin{array}{l}\text { Beef } \\
\text { steers e }\end{array}$ & $\begin{array}{l}\text { Beef } \\
\text { heifers }\end{array}$ \\
\hline $\begin{array}{l}\text { No animals } \\
\text { Live wt (kg) }\end{array}$ & 4 & 2 & 4 & 5 & 4 & 7 \\
$\begin{array}{l}\text { Whole body (WB) } \\
\text { oxygen uptake (mmol/h) }\end{array}$ & 534 & 491 & 660 & 221 & 198 & 318 \\
$\begin{array}{l}\text { Oxygen uptake, \% WB } \\
\text { PDV }\end{array}$ & 5259 & 9747 & 12219 & 3371 & 2999 & 4167 \\
Liver & 25 & 18 & 20 & 21 & 24 & 25 \\
TS & - & - & 25 & 17 & 23 & 21 \\
\hline & - & - & 45 & 38 & 46 & 46 \\
\hline
\end{tabular}

and the liver 1-3\% (Smith and Baldwin, 1974; Doreau et al, 1985; Jones et al, 1985). Therefore, splanchnic tissues account for $35-50 \%$ of HE which is a disproportionately high rate of oxidative metabolism relative to their contribution to body mass. Because these proportions or amounts are substantial, they are attractive targets for ways to improve overall energetic efficiency of cattle.

Absolute rates predictably increase with lactation (table I) or with increased intake (Webster et al, 1975; Ferrell, 1988; Reynolds et al, 1986 Huntington et al, 1988). Diet-related responses in amounts or proportions of oxygen uptake by PDV of steers fed legume or grass silage (Huntington et al, 1988) eluded statistical significance; however, increased intake of concentrate by beef heifers decreased oxygen uptake by PDV (Reynolds and Tyrrell, 1989).

\section{NET NUTRIENT FLUX ACROSS PDV AND LIVER}

\section{Glucose}

In the preponderance of reported studies encompassing a wide range of diets and intakes there is little if any net glucose absorption from dietary sources (see review by Huntington and Reynolds, 1987). This would be expected from consumption of forage diets, but also appears to be the case in cattle consuming substantial amounts of starch. For example, dairy cows consuming about $5 \mathrm{~kg}$ of starch as corn silage per day had net use of glucose $(59 \mathrm{mmol} / \mathrm{h})$ by PDV (Reynolds et al, 1988). Post-ruminal infusion of glucose or starch in a nonlactating cow, beef heifers and dairy steers (Huntington and Reynolds, 1986; Kreikemeier et al, 1987) 
showed that about two-thirds of the glucose infused and one-third of the starch infused could be accounted for by increased net absorption of glucose. Ostensibly, the rest is used by PDV tissues or further metabolized in the lumen of the intestine. This is suggested by studies with dairy cows (Pehrson et al, 1981) and beef steers (Turgeon et al, 1983) which indicate the maximal capacity for starch disappearance from the intestine was not exceeded in the infusion studies cited.

Recent studies with steers (table II) help explain how substantial passage of glucose (or $\alpha$-linked glucose polymers) from the rumen does not result in net glucose absorption. Partition of net glucose flux across stomach and post-stomach sites within PDV showed net use of glucose by both sites when the diet was alfalfa hay. When high-concentrate (corn) diet was fed, however, net use of glucose by stomach tissues increased, and net absorption of glucose by post-stomach tissues was measured, ostensibly in response to starch appearing in the small intestine (table II). Janes et al (1984) reported a similar response in post-stomach glucose absorption when the diet of sheep was changed from forage to high-concentrate. In vitro studies of rumen mucosa from cattle fed roughage or a high-concentrate diet confirm increased glucose uptake by mucosa in response to the high-concentrate diet with concomitant increases in oxidation of glucose to $\mathrm{CO}_{2}$ and formation of lactate (Harmon, 1986).

Ruminants are eminently capable of gluconeogenesis to meet their metabolic needs (Young, 1977). Net hepatic glucose production $(3.1 \mathrm{~kg} / \mathrm{d})$ of lactating cows previously cited as an example of net glucose use by PDV (Reynolds et al, 1988) was able to meet glucose required for their milk lactose synthesis, leaving $0.8 \mathrm{~kg} / \mathrm{d}$ to meet other glucose requirements. Weighart et al (1986) made similar calculations for lactating cows. In fed cattle propionate is the major glucose precursor, followed by lactate and amino acids (table III). Studies of nonlactating and lactating cows (Baird et al, 1980) show how change in physiological state affects priority of uptake of glucose precursors by the liver to ensure an inverse relationship between glucose availability or propionate supply and use of endogenous precursors by the gut and liver. Fasting decreased gluconeogenesis and caused shifts in the sources of carbon from exogenous sources (propionate) to endogenous sources (lactate, amino acids and glycerol).

Table II. Net glucose flux (mmol/h) across stomach and post-stomach sites of portal-drained viscera (PDV) of steers fed alfalfa hay or a high concentrate diet. a Diet differ $(P<0.05)$.

Site

Reynolds and Huntington (1988a)

Huntington (1989)

Alfalfa High-concentrate Alfalfa High-concentrate

$\begin{array}{lllll}\text { PDV } & -35 & -1 \mathrm{a} & -53 & -4 \mathrm{a} \\ \text { Stomach } & -11 & -30 & -13 & -20 \\ \text { Post-stomach } & -24 & +29 \mathrm{a} & -40 & +16 \mathrm{a}\end{array}$


Table III. Maximal contribution of glucose precursors to hepatic gluconeogenesis in cattle. a Huntington and Eiseman (1988); b Reynolds et al (1988); c Lomax and Baird (1983); data from lactating and

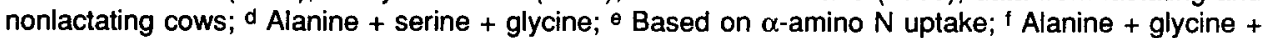
serine + threonine.

\begin{tabular}{|c|c|c|c|c|}
\hline & \multirow[t]{2}{*}{ Beef steers a } & \multirow{2}{*}{$\begin{array}{l}\text { Lactating } \\
\text { cows } b\end{array}$} & \multicolumn{2}{|c|}{ Dairy cows ${ }^{c}$} \\
\hline & & & Fed & Fasted \\
\hline $\begin{array}{l}\text { Net hepatic glucose } \\
\text { production, } \mathrm{mmol} / \mathrm{h}\end{array}$ & 180 & 713 & 324 & 74 \\
\hline $\begin{array}{l}\text { \% contribution to glu } \\
\text { propionate } \\
\text { L-lactate } \\
\text { amino acids } \\
\text { pyruvate } \\
\text { glycerol }\end{array}$ & $\begin{array}{l}72.8 \\
13.1 \\
12.1 \mathrm{~d}\end{array}$ & $\begin{array}{l}55.4 \\
17.5 \\
16.5^{e}\end{array}$ & $\begin{array}{r}46.0 \\
16.0 \\
8.6 \\
0.6 \\
0.8\end{array}$ & $\begin{array}{c}0.8 \\
74.4 \\
14.6 \\
8.1 \\
19.5\end{array}$ \\
\hline Total & 98.0 & 89.4 & 72.0 & 117.4 \\
\hline
\end{tabular}

\section{VOLATILE FATTY ACIDS, LACTATE AND KETONES}

Volatile fatty acids (VFA) are the predominant source of energy absorbed from dietary sources. As do other tissues, the PDV use VFA as energy sources, which means the rates and pattern of VFA production in the rumen are not the same as their rates and pattern of absorption. Several studies with sheep and cattle (Bergman and Wolff, 1971; Pethick et al, 1981; Huntington et al, 1983; Seal et al, 1989) show that $\approx 33 \%$ of the acetate and $50-80 \%$ of the propionate produced in the rumen are metabolized by PDV. The liver further alters the dietary supply by removing propionate and 4- and 5-carbon VFA from portal blood, and adding acetate from endogenous production (Lomax and Baird, 1983; Huntington and Eisemann, 1988; Reynolds et al, 1988).
There is net production of lactate by PDV; L-lactate predominates, but D-lactate is absorbed by cattle fed high grain diets (Huntington et al, 1981; Harmon et al, 1985). As discussed previously, L-lactate is used by the liver for gluconeogenesis (Huntington et al, 1981); D-lactate is oxidized (Harmon et al, 1983; Giesecke and Stangassinger, 1978, 1979).

The ketones $\beta$-hydroxybutyrate and to a lesser extent acetoacetate are produced by PDV. About $90 \%$ of butyrate produced in the rumen is oxidized by PDV (Bergman and Wolff, 1971) and $\beta$-hydroxybutyrate is a major product of that metabolism. The liver also produces $\beta$-hydroxybutyrate (Heitmann et al, 1987; Reynolds et al, 1988). Net uptake of $n$-butyrate and nonesterified fatty acids by the liver of lactating cows accounts maximally for $76-83 \%$ of $\beta$-hydroxybutyrate release (Lomax and Baird, 1983; Reynolds et al, 1988). Fasting causes the PDV to shift from production to 
net use of ketones (Lomax and Baird, 1983).

\section{AMINO ACIDS}

Like glucose and VFA, the PDV uses amino acids from dietary and endogenous sources (Tagari and Bergman, 1978). For example, the PDV uses more glutamate and glutamine than is available from dietary sources (Harmon and Avery, 1987; Reynolds and Huntington, 1988a). Glutamate and glutamine are oxidized, and amino groups are transmitted to form alanine, serine and glycine (Bergman and Pell, 1985). In general, use of amino acids by PDV is related to the high rate of protein synthesis in PDV (Lobley et al, 1980). This use of amino acids by PDV explains at least in part why it has been difficult to show effects of diet on either rates or proportions of net absorption of amino acids or $\alpha$-amino N (Prior et al, 1981; Huntington, 1987; Huntington et al, 1988).

The liver removes amino acids from portal supply in amounts that vary among individual acids, thereby further modulating the rates and proportions of amino acids available for the rest of the body (Baird et al, 1975; Bergman and Pell, 1985; Huntington and Eisemann, 1988). The liver is a major participant in $\mathrm{N}$ shuttles among various tissues that involve alanine, glycine, glutamate, glutamine, arginine, ornithine and citrulline (Bergman and Pell, 1985). The livers of lactating cows removed $43 \%$ of net PDV supply of $\alpha$-amino $N$ (Reynolds et al, 1988) and the livers of growing beef steers removed $24 \%$ (Huntington and Eisemann, 1988). Liver removal of $\alpha$ amino $\mathrm{N}$ decreased in steers changed from hay to a high-grain diet, resulting in greater splanchnic release with constant PDV absorption (Huntington, 1989). Guerino et al (1988) increased PDV absorption of $\alpha$-amino $\mathrm{N}$ abomasal infusion of casein into steers fed a high-grain diet, but liver removal increased correspondingly and splanchnic release of $\alpha$-amino did not change.

\section{AMMONIA AND UREA}

Ammonia and urea are significant components in overall $\mathbf{N}$ metabolism of cattle (table IV). Over a variety of diets, $\mathrm{N}$ digestibility ranged from $61-72 \%$ of $N$ intake. Urine $\mathrm{N}$ and retained $\mathrm{N}$ varied with intake and productive state. Net PDV production of ammonia $\mathrm{N}$ ranged from $16-95 \%$ of $\mathrm{N}$ intake and was directly related to $N$ intake. Net removal of urea N by PDV (transfer from blood to the lumen of the gut) ranged from $15-37 \%$ of $\mathrm{N}$ intake, and net production of $\alpha$-amino $\mathrm{N}$ ranged from $18-36 \%$ of $\mathrm{N}$ intake. With the exception of beef heifers fed the high-concentrate diet (table IV), net absorption of ammonia $\mathrm{N}$ was equal to or greater than net absorption of $\alpha$-amino $\mathrm{N}$. Net transfer of urea $\mathrm{N}$ and net absorption of $\alpha$-amino are generally similar.

Diet composition affected site of urea $\mathrm{N}$ flux across PDV of steers (table V). In steers fed hay, urea was transferred predominantly to the post-stomach. When the same steers were fed a high-concentrate diet, urea flux shifted to the stomach (rumen). Earlier work with ${ }^{15} \mathrm{~N}$ similarly showed transfer of urea $\mathrm{N}$ was predominantly to the lower gut of sheep fed forage (Nolan and Leng, 1972). Bunting et al (1989) used radioisotopes to show increased protein intake of calves increased production of ammonia in the rumen, increased urea synthesis, and doubled the percentage of total gastrointestinal urea degradation occurring in the rumen. Net production of ammonia $\mathrm{N}$ in steers fed twice daily was 2.7: 1 stomach: poststomach for the hay diet and about $1: 1$ for 
Table IV. Nitrogen metabolism in cattle. a DN, digested $N$; UN, urine $N ; T N$, tissue $N ; M N$, milk $N$; $\mathrm{NH}_{3} \mathrm{~N}$, net portal absorption of ammonia, AAN, net portal absorption of $\alpha$-amino $\mathrm{N}$ or amino acids; b Net transfer of urea $\mathrm{N}$ across portal-drained viscera to the lumen of the gut; does not include salivary urea; c Huntington (1984b); d Reynolds et al (1988); o Huntington et al (1988); ‘ Reynolds and Tyrrell (1989); g Huntington and Prior $(1983 ; 1985)$.

\begin{tabular}{|c|c|c|c|c|c|c|c|c|c|}
\hline \multirow[t]{2}{*}{ Animal } & \multirow[t]{2}{*}{ Diet } & \multirow{2}{*}{$\begin{array}{l}\text { Nintake } \\
(g / d)\end{array}$} & \multicolumn{7}{|c|}{ Percentage of N intake a } \\
\hline & & & $D N$ & UN & $T N$ & $M N$ & $\mathrm{NH}_{3}$ & I Urea & LAN \\
\hline Lactating cow $d$ & 60:40 Silage: supplement & 387 & 69 & 38 & 2 & 30 & 38 & 24 & 35 \\
\hline Lactating cow $\mathrm{d}$ & 60:40 Silage: supplement & 388 & 69 & 45 & -14 & 38 & 47 & 37 & 36 \\
\hline Holstein steer ${ }^{\theta}$ & $\begin{array}{l}\text { Alfalfa silage } \\
\text { Grass silage }\end{array}$ & $\begin{array}{l}233 \\
178\end{array}$ & $\begin{array}{l}71 \\
61\end{array}$ & $\begin{array}{l}58 \\
48\end{array}$ & $\begin{array}{l}13 \\
12\end{array}$ & & $\begin{array}{l}64 \\
55\end{array}$ & $\begin{array}{l}15 \\
20\end{array}$ & $\begin{array}{l}18 \\
24\end{array}$ \\
\hline Beef heifer & $\begin{array}{l}\text { 75:25 Hay: concentrate } \\
\text { 25:75 Hay: concentrate }\end{array}$ & $\begin{array}{l}161 \\
132\end{array}$ & $\begin{array}{l}69 \\
72\end{array}$ & $\begin{array}{l}61 \\
58\end{array}$ & $\begin{array}{r}7 \\
13\end{array}$ & & $\begin{array}{l}34 \\
51\end{array}$ & $\begin{array}{l}33 \\
35\end{array}$ & $\begin{array}{l}32 \\
36\end{array}$ \\
\hline Beef heifer $g$ & 10:90 Hay: concentrate & $\begin{array}{l}34 \\
64 \\
93\end{array}$ & $\begin{array}{l}70 \\
66 \\
62\end{array}$ & $\begin{array}{l}88 \\
60 \\
36\end{array}$ & $\begin{array}{r}-20 \\
4 \\
25\end{array}$ & & $\begin{array}{l}35 \\
20 \\
16\end{array}$ & $\begin{array}{l}20 \\
22 \\
19\end{array}$ & $\begin{array}{l}28 \\
30 \\
33\end{array}$ \\
\hline
\end{tabular}

Table V. Net flux a (mmol/h) of ammonia $\mathrm{N}$ and urea $\mathrm{N}$ across stomach and post-stomach sites of portal-drained viscera (PDV) of steers fed alfalfa hay or a high concentrate diet. a Positive numbers indicate absorption, negative numbers indicate transfer from blood to the lumen of the gut; b Fluxes measured at meal time in steers fed twice daily; $c$ Fluxes measured in steers fed 12 equal meals daily; $d$ Within studies, diet means differ $(P<0.05)$.

Site

Reynolds and Huntington (1988a)

Huntington (1989)

Alfalfa High-concentrate Alfalfa High-concentrate

$\begin{array}{lrccc}\text { Ammonia N } & & & & \\ \text { PDV } & 348 & 154 \mathrm{~d} & 291 & 128 \mathrm{~d} \\ \text { Stomach } & 253 & 74 & 195 & 85 \\ \text { Post-stomach } & 95 & 80 & 96 & 43 \\ & & & & \\ \text { Urea N } & & & -79 & -76 \\ \text { PDV } & -96 & -101 & -24 & -71 \\ \text { Stomach } & 9 & -68 & -55 & -5 \mathrm{~d}\end{array}$


the high-concentrate diet (measurements made at meal time). In steers fed 12 meals/d net production of ammonia $\mathrm{N}$ was about 2:1 stomach: post-stomach on both diets (table V), suggesting that about $2 / 3$ of absorbed ammonia $\mathrm{N}$ emanated from ruminal fermentation and tissue metabolism, and one-third from metabolism of $\mathrm{N}$ sources in the lower gut.

The liver receives directly the ammonia $\mathrm{N}$ produced by PDV and essentially removes all of it from blood (Huntington and Eisemann, 1988; Reynolds et al, 1988; Huntington, 1989). Net liver removal can account maximally for 70 to $80 \%$ of urea $\mathrm{N}$ released (Huntington and Eisemann, 1988; Reynolds et al, 1988; Huntington, 1989). The capacity of a healthy liver to remove ammonia is not exceeded with normal diets (Symonds et al, 1981; Orzechowski et al, 1987), even when PDV production is substantial.

\section{ENERGETIC SUMMATION OF PDV AND LIVER METABOLISM}

Baird et al (1975) first published a comprehensive summation of energy flux by PDV of a lactating cow. Energy absorbed as VFA, lactate and ketones, and amino acids summed to $135 \mathrm{MJ} / \mathrm{d}$, which was $84 \%$ of calculated ME intake. Further studies with steers and dairy cows include HE from oxygen uptake by PDV (table VI). In the steers, energy from net absorption plus $\mathrm{HE}$ accounted for $75-91 \%$ of measured ME intake of legume or grass silage. Not all energy sources were measured in all studies with dairy cows, but in lactating cows nutrient absorption plus $\mathrm{HE}$ accounted for $85 \%$ of ME intake. In both steers and cows the largest single source of energy was acetate followed by propionate, except for first lactation cows in which the order was reversed. The third largest source (again

Table VI. Energetic summation of net absorption and oxygen uptake by portal-drained viscera of cattle. a Huntington et al (1988); b Huntington et al (1983); c Huntington and Tyrrell (1985); Reynolds and Huntington (1988b); d Reynolds et al (1988).

\begin{tabular}{|c|c|c|c|c|c|c|c|}
\hline \multirow[b]{3}{*}{ Live weight $(\mathrm{kg})$} & \multicolumn{4}{|c|}{ Holstein steers a } & \multicolumn{3}{|c|}{$\begin{array}{c}\text { Holstein cows } \\
\text { 60:40 Corn silage: supplement }\end{array}$} \\
\hline & \multicolumn{2}{|c|}{$\begin{array}{l}\text { Alfalfa } \\
\text { silage }\end{array}$} & \multicolumn{2}{|c|}{$\begin{array}{c}\text { Orchardgrass } \\
\text { silage }\end{array}$} & \multirow{2}{*}{$\frac{d r y^{b}}{493}$} & \multirow{2}{*}{$\frac{1 \text { st lact }}{496}$} & \multirow{2}{*}{$\frac{2+\text { lact }^{\mathrm{d}}}{645}$} \\
\hline & 320 & 335 & 334 & 345 & & & \\
\hline Dry matter intake $(\mathrm{kg} / \mathrm{d})$ & 5.0 & 7.2 & 5.0 & 6.4 & 5.0 & 14.0 & 15.6 \\
\hline Metabolizable energy intake (MJ/d) & 60 & 84 & 56 & 70 & 59 & 171 & 178 \\
\hline \multicolumn{8}{|l|}{ Net absorption (MJ/d) } \\
\hline Acetate & 12.5 & 22.8 & 16.5 & 21.2 & 12.1 & 27.0 & 39.2 \\
\hline Proprionate & 9.2 & 14.6 & 8.0 & 11.0 & 6.1 & 27.2 & 30.1 \\
\hline Other VFA & 4.7 & 7.2 & 3.7 & 4.6 & 4.3 & 11.0 & 15.9 \\
\hline L-lactate & 3.0 & 3.9 & 2.4 & 3.3 & 2.0 & 4.9 & 7.0 \\
\hline$\beta$-Hydroxybutyrate & - & - & - & - & - & - & 12.1 \\
\hline amino-acid & 3.0 & 7.1 & 5.4 & 7.2 & - & 18.9 & 27.1 \\
\hline Oxygen uptake (MJ/d) & 12.6 & 16.3 & 12.6 & 16.7 & - & 18.9 & 27.1 \\
\hline
\end{tabular}


except for first lactation cows) was $\mathrm{HE}$ from oxygen uptake and fourth was energy from amino acids. Other VFA, L-lactate and $\beta$-hydroxybutyrate supplied lesser amounts of energy. L-lactate plus VFA accounted for $41-57 \%$ of ME intake (table VI). A similar percentage of ME intake was attributable to L-lactate and VFA in beef heifers fed a high-concentrate diet (46\%; Huntington and Prior, 1983). Sources of ME not accounted for in table VI include heat of fermentation, absorption of longchain fatty acids, and absorption of other nitrogenous compounds such as nucleic acids and peptides (Webb, 1986).

Dietary effects on sources of energy absorbed or HE by PDV were slight in the steers. Steers fed alfalfa silage absorbed more energy as branched-chain VFA and $n$-valerate than steers fed grass silage (table VI). Comparison of differences between intake within silages suggests some dietary effects; compared to the grass silage, the alfalfa silage caused a greater increment as acetate (40 vs $30 \%$ of the increment) and a lesser increment as $\mathrm{HE}$ (15 vs $26 \%$ of the increment) (Huntington et al, 1988). This may explain in part some of the metabolism behind greater efficiency of energy use by ruminants fed legumes compared to grasses (Rattray and Joyce, 1970; Tyrrell et al, 1982; Thompson et al, 1985; Varga et al, 1987).

Nonlactating and lactating cows were fed the same diet, but at different intakes to support production (table VI). Compared to non-lactating cows, lactating cows absorbed a greater percentage of ME intake as propionate (16 vs $10 \%$ ). The percentage of ME absorbed as acetate was less by cows in first lactation (16\%) than dry cows $(20 \%)$ or older lactating cows $(22 \%)$.

\section{CONCLUSIONS}

Five major points can be derived from information in this review. First, blood flow throught PDV of cattle is highly and positively correlated with their ME intake, which provides a transport for increased absorption of nutrients. Second, the PDV and liver are metabolically active at rates disproportionately greater than their contribution to body tissue mass; together, they can account for one-half of HE. Third, altough cattle derive little if any glucose directly from dietary sources, they are metabolically designed and tuned to synthesize glucose, which provides a use for propionate and lactate absorbed by PDV. Fourth, nonprotein $\mathrm{N}$ sources are significant participants in overall $\mathrm{N}$ metabolism which is orchestrated by the liver. Fifth, dietary or physiological effects on nutrient absorption and liver metabolism are most evident for VFA, ammonia and urea, which emphasizes the close and perhaps obligate interrelation between energy and $\mathrm{N}$ metabolism in cattle.

These points show the central role gut and liver tissues play in energy metabolism, both by regulating and modulating dietary energy sources and by virtue of their high energy expenditures. It follows then that a small change in mode or efficiency of splanchnic metabolism could have a major effect on the whole animal's response to physiological state or nutrition.

\section{REFERENCES}

Agricultural Research Council (1980) Nutrient Requirements of Livestock. Commonwealth Agricultural Bureaux, UK 
Baird GD, Lomax MA, Symonds HW, Shaw SR (1980) Net hepatic and splanchnic metabolism of lactate, pyruvate and propionate in dairy cows in vivo in relation to lactation and nutrient supply. Biochem J 186, 47-57

Baird GD, Symonds HW, Ash R (1975) Some observations on metabolite production and utilization in vivo by the gut and liver of adult dairy cows. J Agric Sci (Camb) 85, 281-296

Bergmann EN, Pell JM (1985) Integration of amino acid metabolism in the ruminant. In: Herbivore Nutrition in the Subtropics and Tropics (Gilchrist FMC, Mackie RI, eds) The Science Press, Johannesburg, S Africa, 613628

Bergman EN, Wolff JE (1971) Metabolism of volatile acids by liver and portal-drained viscera in sheep. Am J Physiol 221, 586-592

Bunting LD, Boling JA, Mackown CT (1989) Effect of protein level on nitrogen metabolism in the growing bovine. I. Nitrogen recycling and intestinal protein supply in calves. I Anim Sci 67, 810-819

Burrin DG, Ferrell CL, Britton RA (1989) Effect of feed intake of lambs on visceral organ growth and metabolism. In: Proc 11th EAAP Symposium on Energy Metabolism of Farm Animals, Lunteren, Netherlands (Van Der Honing $\mathrm{Y}$, Close $\mathrm{WH}$, eds), Eur Assoc Anim Prod Publ No. 43, 103-106

Carr SB, Jacobson DR (1968) Method for measurement of gastrointestinal absorption in normal animals, combining portal-carotid difference and telemetered portal flow by Doppler shift. J Dairy Sci 51, 721-729

Doreau M, Robelin J, Lestrade A (1985) Effects of physiological state and body fatness on digestive-tract weight and composition in the dairy cow. Livestock Prod Sci 12, 379-385

Durand DD, Bauchart, LeFaivre J, Donnat JP (1988) Method for continuous measurement of blood metabolite hepatic balance in conscious preruminant calves. I Dairy Sci 71 , 1632-1637

Eisemann JH, Huntington GB (1987) Metabolism in two tissue beds of steers and effects of clenbuterol. J Anim Sci 65 (suppl. 1), 250 (abstr)

Ferrrel CL (1988) Contribution of visceral organs to animal energy expenditures. J Anim Sci (suppl 3), 23-34
Giesecke D, Stangassinger M (1978) Untersuchungen zur Genese und Biochemie der Pansenacidose. V. Kinetic der elimination von $D(-)$ Milchsaure aus dem Blut. $Z b /$ Vet Med A25, 327-337

Giesecke D, Stangassinger M (1979) Untersuchungen zur Genese und Biochemie der Pansenacidose. VII. Oxydationsrate und quantitative Gluconeogenesis aus d-Lactat$\left({ }^{14} \mathrm{C}\right)$ bei Ziegen. Zb/ Vet Med A26, 85-94

Gross KL, Harmon DL, Avery TB (1988) Net portal nutrient flux in steers fed diets containing wheat and sorghum grain alone or in combination. $J$ Anim Sci 66, 543-551

Guerino F, Huntington G, Erdman R (1988) Net portal and hepatic flux of nitrogenous compounds by beef steers abomasally infused with casein. J Anim Sci 66 (suppl 1), 486 (abstr)

Harmon DL (1986) Influence of dietary energy intake and substrate addition on the in vitro metabolism of glucose and glutamine in rumen epithelial tissue. Comp Biochem Physiol 85B, 643-647

Harmon DL, Avery TB (1987) Effects of dietary monensin and sodium propionate on net nutrient flux in steers fed a high-concentrate diet. J Anim Sci 65, 1610-1616

Harmon DL, Avery TB, Huntington GB, Reynolds PJ (1988) Influence of ionophore addition to roughage and high-concentrate diets on portal blood flow and net nutrient in cattle. Can J Anim Sci 68, 419-429

Harmon DL, Britton RA, Prior RL (1983) Influence of diet on glucose turnover and rates of gluconeogenesis, oxidation and turnover of $D(-)$-lactate in the bovine. J Nutr 113, 1842-1850

Harmon DL, Britton RA, Prior RL, Stock RA (1985) Net portal absorption of lactate and volatile fatty acids in steers experiencing glucose-induced acidosis or fed a $70 \%$ concentrate diet ad libitum. J Anim Sci 60, 500-569

Heitmann RN, Dawes DJ, Sensenig SC (1987) Hepatic ketogenesis and peripheral ketories body utilization in the ruminant. $J$ Nutr 117 , 1174-1180

Huntington G (1984a) Relationship of portal blood flow to metabolizable energy intake of cattle. Can J Anim Sci 64 (suppl), 16 (abstr) 
Huntington GB (1984b) Net absorption of glucose and nitrogenous compounds by lactating Holstein cows. J Dairy Sci 67, 19191927

Huntington GB (1987) Net absorption from portal-drained viscera of nitrogenous compounds by beef heifers fed on diets differing in protein solubility or degradability in the rumen. Br J Nutr 57, 109-114

Huntington GB (1989) Hepatic urea synthesis and site and rate of urea removal from blood of beef steers fed alfalfa or a high concentrate diet. Can J Anim Sci 69, 215-223

Huntington GB, Eisemann JH (1988) Regulation of nutrient supply by gut and liver tissues. $J$ Anim Sci 66 (suppl 3), 35-48

Huntington G, Eisemann J, Whitt J (1988) Proportions of whole body blood flow and oxygen uptake attributable to gut and liver of beef steers. J Anim Sci 66 (suppl 1), 147 (abstr)

Huntington GB, Prior RL (1983) Digestion and absorption of nutrients by beef heifers fed a high concentrate diet. J Nutr 113, 2280-2288

Huntington GB, Prior RL (1985) Net absorption of amino acids by portal-drained viscera and hind half of beef cattle fed a highconcentrate diet. J Anim Sci 60, 1491-1499

Huntington GB, Prior RL, Britton RA (1981) Glucose and lactate absorption and metabolic interrelationships in steers changed from low to high concentrate diets. $J$ Nutr 111,1164 1172

Huntington GB, Reynolds CK (1987) Oxygen consumption and metabolite flux of bovine portal-drained viscera and liver. $J$ Nutr 117 , 1167-1173

Huntington GB, Reynolds PJ (1986) Net absorption of glucose, L-lactate, volatile fatty acids and nitrogenous compounds by bovine given abomasal infusions of starch or glucose. $J$ Dairy Sci 69, 2428-2436

Huntington GB, Reynolds CK, Stroud BH (1989) Techniques for measuring blood flow in splanchnic tissues of cattle. $J$ Dairy Sci 72 , 1583-1595

Huntington GB, Reynolds PJ, Tyrrell HF (1983) Net absorption and ruminal concentrations of metabolites in nonpregnant dry Holstein cows before and after intraruminal acetic infusion. J Dairy Sci 66, 1901-1908
Huntington GB, Tyrrell HF (1985) Oxygen consumption by portal-drained viscera of cattle: comparison of analytical techniques and relationship to whole body oxygen consumption. J Dairy Sci 68, 2727-2731

Huntington GB, Varga GA, Glenn BP, Waldo DR (1988) Net absorption and oxygen consumption by Holstein steers fed alfalfa or orchardgrass silage at equalized intakes. J Anim Sci 66, 1292-1302

Janes AN, Parker DS, Weekes TEC, Armstrong DG (1984) Mesenteric venous blood flow and net absorption of glucose in sheep fed dried grass or ground maize-based diets. J Agric Sci (Camb) 103, 549-553

Jones SDM, Rompala RE, Jeremiah LE (1985) Growth and composition of the empty body in steers of different maturity types fed concentrate or forage diets. J Anim Sci 60, 427-433

Kreikemeier KK, Harmon DL, Avery TB, Brandt RT (1987) Starch and glucose utilization in the small intestine of steers. J Anim Sci 66 (suppl 1), 469 (abstr)

Lobley GE, Milne V, Lovie J, Reeds PJ, Pennie $K(1980)$ Whole body and tissue protein synthesis in cattle. Br J Nutr 43, 491-502

Lomax MA, Baird GD (1983) Blood flow and nutrient exchange across the liver and gut of the dairy cow. Br J Nutr 49, 481-496

McGuire MA, Beede DK, DeLorenzo MA, Wilcox CJ, Huntington GB, Reynolds CK, Collier RJ (1989) Effects of thermal stress and level of feed intake on portal plasma flow and net fluxes or metabolites in lactating Holstein cows. J Anim Sci 67, 1050-1060

Nolan JV, Leng RA (1972) Dynamic aspects of ammonia and urea metabolism in sheep. $\mathrm{Br} J$ Nutr 27, 177-194

Orzechowski A, Motyl T, Pierzynowski G, Barey W (1987) Hepatic capacity for ammonia removal in sheep. J Vet Med A34, 108-112

Pehrson B, Johnson U, Knutsson M (1981) The digestion of starch in the small intestines of dairy cows. Zb/ Vet Med A 28, 241-246

Pethick DW, Lindsay DB, Barker PJ, Northrop AJ (1981) Acetate supply and utilization by the tissues of sheep in vivo. Br J Nutr 46, 97 109

Prior RL, Huntington GB, Britton RA (1981) Influence of diet on amino acid absorption in beef cattle and sheep. J Nutr 111, 2212-2222 
Rattray PV, Joyce JP (1970) The nutritive value of white clover and perennial ryegrass for young sheep. I. Nitrogen retention studies and associated animal performance. $N Z J$ Agric Res 13, 778-791

Reynolds CK, Huntington GB (1988a) Partiton of portal-drained visceral net flux in beef steers. I. Blood flow and net flux of oxygen, glucose and nitrogenous compounds across stomach and post-stomach tissues. $\mathrm{Br} J$ Nutr $60,553-562$

Reynolds PJ, Huntington GB (1988b) Net portal absorption of volatile fatty acids and $L(+)$ lactate by lactating Holstein cows. J Dairy Sci $71,124-133$

Reynolds CK, Huntington GB, Tyrrell HF, Reynolds PJ (1986) Splanchnic tissue and whole animal oxygen consumption by lactating $\mathrm{Hol}-$ stein cows. J Dairy Sci 69 (suppl 1), 193 (abstr)

Reynolds CK, Huntington GB, Tyrrell HF, Reynolds PJ (1988) Net portal-drained visceral and hepatic metabolism of glucose, L-lactate and nitrogenous compounds in lactating $\mathrm{Hol}-$ stein cows. J Dairy Sci 71, 1803-1812

Reynolds CK, Tyrrell HF (1989) Effects of forage to concentrate ratio and intake on visceral tissue and whole body energy metabolism of growing beef heifers. In: Proc 11th EAAP Symp, Energy Metabolism of Farm Animals, Lunteren, Netherlands (Van Der Honing Y, Close WH, eds). Eur Assoc Animal Prod No $43,151-154$

Rumsey TS, Tyrrell HF, Moe PW (1980) Effect of diethylstilbestrol and synovex-S on fasting metabolism measurement of beef steers. $J$ Anim Sci 50, 160-165

Sasaki Y, Weekes TEC (1986) Metabolic responses to cold. In: Control of Digestion and Metabolism in Ruminants. Proc 6th Intl Symp, Ruminant Physiol (Milligan LP, Grovum WL, Dobson A, eds) Prentice-Hall, Englewood Cliffs, NJ, 326-343

Seal CJ, Sarker A, Parker DS (1989) Rumen propionate production rate and absorption of fermentation end-products into the portal vein of forage and forage-concentrate fed cattle. Proc Nutr Soc 48, 143 A (abstr)

Smith NE, Baldwin RL (1974) Effects of breed, pregnancy and lactation on weight of organs and tissues in cattle. J Dairy Sci 50, 10551060
Symonds HW, Mather DL, Colles KA (1981) The maximum capacity of the liver of the adult dairy cow to metabolize ammonia. Br J Nutr 46, 481-486

Tagari H, Bergman EN (1978) Intestinal disappearance and portal blood appearance of amino acids in sheep. $J$ Nutr 108, 790-803

Thompson GE, Maneson W, Clarke PL, Bell AW (1978) Acute cold exposure and the metabolism of glucose and some of its precursors in the liver of the fed and fasted sheep. Quart $J$ Exp Physio/ 63, 189-199

Thomson DJ, Beever DE, Haines MJ, Cammell $S B$, Evans RT, Dhanoa MS, Austin AR (1985) Yield and composition of milk from Freisan cows grazing either perennial ryegrass or white clover in early lactation. $J$ Dairy Res 52, 17-31

Tyrrell HF, Thomson DJ, Waldo DR, Goering HK (1982) Energy retention and utilization of grass and legume by cattle. Proc Nutr Soc 41, 23A (abstr)

Turgeon OA Jr, Brink DR, Britton RA (1983) Corn particle size mixtures, roughage level and starch utilization in finishing steer diets. $J$ Anim Sci 57, 739-749

Varga GA, Tyrrell HF, Waldo DR, Huntington GB, Glenn BP (1987) Effect of alfalfa or orchardgrass silages on energy and nitrogen utilization for growth by Holstein steers. In: Energy Metabolism of Farm Animals (Moe PW, Tyrrell HF, Reynolds PJ, eds) EAAP Publ 32, Rowman \& Littlefield, Totowa, NJ, 86-89

Wangness PJ, McGilliard AD (1972) Measurement of portal blood flow by dye-dilution. $J$ Dairy Sci 55, 1439-1446

Webb KE Jr (1986) Amino acid and peptide absorption from the gastrointestinal tract. Fed Proc 45, 2268-2271

Webster AJF, Osuji PO, White F, Ingram JF (1975) The influence of food intake on portal blood flow and heat production in the digestive tract of sheep. Br J Nutr 34, 125-139

Weighart M, Slepetis R, Elliot JM, Smith DF (1986) Glucose absorption and hepatic gluconeogenesis in dairy cows fed diets varying in forage content. J Nutr 116, 839-850

Young JW (1977) Gluconeogenesis in cattle: significance and methodology. $J$ Dairy Sci 60 , 1-15 